\title{
DINAMIKA KOMUNIKASI DALAM RESOLUSI KONFLIK SOSIAL
}

\author{
Asri Dewi, Rahmad Hidayat, Miftah F. Widhagda, dan Wahyu Purwanto
}

FISIP Universitas Muhammadiyah Yogyakarta

\begin{abstract}
This study examines the PT Pertamina (Persero) Refinery Unit II CSR program in the field of community development in dealing with social conflicts. This research was conducted at the Tunas Makmur Farmer Group under the auspices of Sungai Pakning in the Kampung Jawa, Sungai Pakning Village, Bukit Batu District, Bengkalis Regency, Riau Province. Kampung Jawa is an isolated area from public facilities and socially marginalized. The location of the Javanese village environment also has a high risk of land and forest fires. This research method uses qualitative methods by collecting data through participatory observation. The results of this study indicate that the communication dynamics of the Tani Tunas Makmur group under the auspices of PT Pertamina (Persero) Sungai Pakning Refinery Unit II in dealing with social conflict through seven key concepts in Goldhaber organizational communication namely process, message, network, interdependent conditions, relationships, environment, and uncertainty. Group communication is supported by cultural proximity between group members.
\end{abstract}

\begin{abstract}
Abstrak: Penelitian ini mengkaji program CSR Kampung Gambut Berdikari PT Pertamina (Persero) Refinery Unit II bidang community development dalam menangani konflik sosial. Penelitian ini dilakukan pada Kelompok Tani Tunas Makmur binaan CSR Sungai Pakning yang berada di Kampung Jawa, Kelurahan Sungai Pakning, Kecamatan Bukit Batu, Kabupaten Bengkalis, Provinsi Riau. Kampung Jawa merupakan daerah yang terisolir dari fasilitas publik dan terpinggirkan secara sosial kemasyarakatan. Letak lingkungan kampung jawa juga memiliki resiko kebakaran lahan dan hutan yang cukup tinggi. Metode penelitian ini menggunakan metode kualitatif dengan pengumpulan data melalui observasi partisipatif. Hasil penelitian ini menunjukkan bahwa dinamika komunikasi kelompok Tani Tunas Makmur binaan CSR PT Pertamina (Persero) Refinery Unit II Sungai Pakning dalam menangani konflik sosial melalui tujuh konsep kunci dalam komunikasi organisasi Goldhaber yaitu proses, pesan, jaringan, keadaan saling tergantung, hubungan, lingkungan, dan ketidakpastian. Komunikasi kelompok tersebut didukung oleh cultural proximity antara anggota kelompok.
\end{abstract}

Kata kunci: CSR, community development, konflik sosial, komunikasi organisasi, cultural proximity.

\section{PENDAHULUAN}

Kompleksitas permasalahan sosial saat ini menjadi semakin sulit. Seiring perkembangan dunia usaha dan perindustrian, maka dampak yang terjadi pada lingkungan pun semakin beragam, baik karena pembangunan infrastruktur, limbah, serta akses jalan yang rusak akibat kegiatan perusahaan. Manusia sebagai makhluk sosial tidak dapat melepaskan diri dari jalinan relasi sosial, dimana manusia selalu akan mengadakan kontak sosial yaitu selalu berhubungan dengan orang lain. Bahkan sebahagian besar dari waktu kita gunakan untuk berkomunikasi.

Mengingat kuantitas berkomunikasi yang dilakukan dan jika dibandingkan dengan kegiatan lainnya, maka dapat dikatakan bahwa komunikasi merupakan salah satu hal yang penting bagi manusia. Tidak ada suatu yang lebih penting bagi sebagian besar orang selain berinteraksi dengan orang lain. Seorang individu dalam kehidupan sehari hari tidak lepas dari interaksi individu lainnya. Seringkli ditemui dalam pemenuhan kebutuhannya, beberapaindividu saling berkumpul dan menjalin relasi pada akhirnya disebut sebagai sebuah kelompok. Kelompok menjadi sebuah sistem sosial, dalam pembentukannya dibutuhkan adanya saling ketergantungan (interdependence) dan saling berhubungan (interrelated).

Begitu pentingnya interaksi ini sehingga apabila tidak dilakukan dalam jangka waktu lama, akan menimbulkan depresi, kurang percaya diri dan kesulitan dalam memenuhi kebutuhan dasar bagi kehidupan sehari-hari. Beberapa alasan umum tentang mengapa seseorang menjalin hubungan, yaitu mengurangi kesepian yang muncul ketika kebutuhan interaksi akrab tidak terpenuhi, menguatkan dorongan karena semua manusia membutuhkan dorongan semangat dan salah satu 
cara terbaik untuk mendapatkannya adalah dengan interaksi antar manusia.

Komunikasi yang bersifat dinamis menjadi garis yang menghubungkan anggota-anggota dalam kelompok tersebut, dan menimbulkan adanya dinamika komunikasi. Dinamika komunikasi pada sebuah kelompok didefinisikan sebagai aktivitas yang dilakukan ketika dua atau lebih orang menyampaikan pesan secara tatap muka dan mereka menyadari keberadaan anggota lain di dalam kelompok serta daya kesamaan kepentingan yang dinyatakan sebagai tujuan untuk mencapai kesepakatan bersama (Goldhaber, 1993).

Sumber ekonomi kelurahan sungai pakning diperoleh dari sumber-sumber pemerintahan seperti APBN melalui anggaran dana desa (AAD), APBD Provinsi Riau, APBD kabupaten Bengkalis, anggaran SKPD, dan sumber-sumber lain dari partisipasi pihak swasta dan swadaya masyarakat sedangkan sumber ekonomi masyarakat didapatkan dari penghasilan yang dihasilkan dari berbagai profesi yang dikerjakan oleh masyarakat yang mayoritas berprofesi sebagai buruh, karyawan, maupun pedagang. Secara tingkat ekonomi, masyarakat kelurahan sungai pakning berada pada tingkat ekonomi menengah dengan penghasilan berkisar antara Rp. 1.000. 000-Rp. 5.000.000/KK/bulan. Angka ini masih berada dikisaran rerata angka upah minimum regional kabupaten bengkalis sebesar $\mathrm{Rp}$. 2.685.547. Masih terdapat keluarga prasejahtera yang perlu mendapat perhatian.

Kampung Jawa merupakan salah satu daerah yang terletak di Kelurahan Sungai Pakning. Kampung Jawa merupakan daerah yang terisolir dari fasilitas publik dan terpinggirkan secara sosial kemasyarakatan. Letak lingkungan kampung jawa yang berbatasan langsung dengan perkebunan sawit salah satu perusahaan swasta perkebunan sehingga memiliki resiko kebakaran lahan dan hutan yang cukup tinggi.

Di Kampung Jawa, kondisi infrastruktur jalan cukup buruk dengan kombinasi antara jalan beton dan jalan tanah. Akses jalan menuju kampung jawa cukup sulit karena harus memutar melalui jalan lingkar dumai dengan jarak tempuh lebih jauh, sedangkan apabila ingin lebih cepat harus melalui kilang pertamina terlebih dahulu. Hal ini mengakibarkan masyarakat Kampung Jawa kesulitan untuk mengakses kebutuhan sehari-hari.

Infrastruktur komunikasi cukup baik di Kelurahan Sungai Pakning, namun jangkauan komunikasi belum mencapai ke seluruh daerah terutama daerah Kampung Jawa. Di lingkungan Kampung Jawa, telah terdapat Pusat Kesehatan Kelurahan (Puskeskel). Namun berdasarkan observasi di lapangan, Puskeskel telah sering tidak beroperasi (tutup), sehingga masyarakat sulit untuk mendapatkan layanan kesehatan yang berkualitas. Di Kampung Jawa juga, tidak ditemukan adanya fasilitas ekonomi yang dapat diakses masyarakat untuk mendapatkan bantuan permodalan. Masyarakat kesulitan untuk mengembangkan usaha yang membutuhkan bantuan modal tambahan.

Berdasarkan penjelasan tersebut, dapat dilihat bahwa Kampung Jawa merupakan daerah yang terisolir secara akses infrastruktur, ekonomi, komunikasi, serta kesehatan. Sebagai bentuk upaya perusahaan dalam menyelasaikan permasalahan tersebut, PT Pertamina RU II Sungai Pakning memiliki program Tanggung Jawab Sosial Perusahaan atau juga dikenal dengan program Corporate Social Responsibility $(C S R)$.

Di Kampung Jawa, Kelurahan Sungai Pakning merupakan salah satu wilayah sasaran program PT. Pertamina RU II Sungai Pakning, karena secara garis wilayah merupakan Ring 1 dari perusahaan. Program CSR Kampung Gambut Berdikari merupakan salah satu solusi bagi masyarakat untuk menanggulangi permasalahan sosial yang ada di Kampung Jawa, namun keberlangsungan program ini membutuhkan komunikasi yang baik antar elemen baik dari pihak kelompok, perusahaan, serta masyarakat luas.

\section{METODE}

Metode penelitian ini menggunakan metode kualitatif dengan pengumpulan data melalui observasi partisipatif. Informan penelitian ini adalah anggota kelompok Tani Tunas Makmur. Metode ini melihat pengalaman individu/orga- 
nisasi secara utuh, sehingga tidak membatasi pernyataan individu/organisasi ke dalam hipotesis tertentu.

\section{HASIL DAN PEMBAHASAN}

Peran komunikasi sebagai suatu alat dalam penyampaian pesan juga memiliki peran penting dalam keberlangsungan suatu organisasi. Kelompok Tani Tunas Makmur merupakan kelompok yang terletak di kelurahan sungai pakning, bengkalis dengan keadaan geografis mayoritas lahan gambut. Seperti halnya kasus kebakaran lahan yang seringkali terjadi di Provinsi Riau, di kelurahan sungai pakning juga sering terjadi kebakaran lahan gambut baik dikarenakan kemarau maupun perilaku manusia.

Dalam menanggulangi permasalahan tersebut, kelompok Tani Tunas Makmur dibantu oleh PT Pertamina RU II Sungai Pakning mengolah lahan gambut tersebut menjadi pertanian nanas. Dan hasil pertanian tersebut dioleh oleh kelompok kerja (Pokja) UMKM Pengolahan yang akhirnya menghasilkan berbagai produk makanan yang dapat membantu meningkatkan kesejahteraan ekonomi kelompok Tani Tunas Makmur.

Keberlangsungan aktivitas kelompok tersebut melalui beberapa tahapan komunikasi untuk dapat menanggulangi krisis yang terjadi di kelurahan sungai pakning. Menurut Goldhaber, ada tujuh tahapan kunci komunikasi yang menjadi aspek yang perlu diperhatikan dalam komunikasi organisasi. Komunikasi organisasi dapat dikatakan berjalan dengan baik jika hal-hal berikut direspon dengan baik.

Berikut dipaparkan tujuh tahapan komunikasi berdasarkan penelitian di lapangan.

\section{Proses}

Suatu organisasi adalah suatu sistem terbuka yang dinamis yang menciptakan dan saling mengukur pesan diantara anggotanya. Karena gejala menciptakan dan menukar informasi ini berjalan terus-menerus dan tidak ada hentihentinya maka dikatakan sebagai suatu proses. Kelompok Tani Tunas Makmur yang beranggotakan 45 orang telah melalui tahap proses yang dinamis hingga menghasilkan beberapa pojka seperti Pojka Pertanian Nanas, Pokja Masya- rakat Peduli Api dan Arboretum, serta Pojka Pengolahan Produk Nanas.

\section{Pesan}

Pesan adalah susunan simbol yang penuh makna tentang orang, objek, serta kejadian yang dihasilkan oleh interaksi manusia. Pesan dapat di klasifikasikan atas pesan verbal dan nonverbal, internal dan eksternal, serta perangkat keras dan lunak.

Proses penyampaian pesan kelompok Tani Tunas Makmur telah menggunakan beberapa klasifikasi. Dalam pelaksanaan aktivitas internal maupun eksternal kelompok, anggota seringkali menggunakan pesan verbal dalam bentuk percakapan, pidato, dan memo. Komunikasi juga dibangun antar anggota kelompok maupun pihakpihak eksternal lainnya seperti pihak Pertamina RU II Sungai Pakning, pemerintah daerah, dan masyarakat setempat.

\section{Jaringan}

Organisasi terdiri dari satu satu seri orang yang tiap-tiapnya menduduki posisi atau peranan tertentu dalam organisasi. Ciptaan dan pertukaran pesan dari orang-orang ini sesamanya terjadi melewati suatu set jalan kecil yang dinamakan jaringan komunikasi.

Jaringan komunikasi dapat dilihat dari dua prespektif. Pertama, kelompok kecil sesuai dengan sumber daya yang dimilikinya akan mengembangkan pola komunikasi yang menggabungkan beberapa struktur jaringan komunikasi. Jaringan komunikasi ini merupakan sistem komunikasi umum yang akan digunakan oleh kelompok dalam mengirimkan pesan dari satu orang ke orang lain. Kedua, jaringan komunikasi dapat dipandang sebagai struktur formal yang diciptakan oleh organisasi sebagai sarana komunikasi organisasi (Wiryanto, 2006).

Dalam hal ini, peran kelembagaan dalam suatu kelompok berperan penting dalam luasnya ruang lingkup kelompok. Struktur kelembagaan kelompok Tani Tunas Makmur sendiri telah terbentuk dan berjalan sesuai tugas pokok dan fungsi masing-masing jabatan. Terdiri dari ketua, sekretaris, bendahara, serta ketua masing-masing Pokja. Sistem yang digunakan adalah Top-down 
communication. Pesan-pesan yang berkaitan dengan kelompok disampaikan kepada ketua kelompok, dan ketua akan menyampaikan kepada anggota maupun Pojka yang bersangkutan yang mana hal ini mengakibatkan informasi yang disampaikan terpusat dan dapat mengurangi resiko miskomunikasi antar anggota.

\section{Keadaan Saling Tergantung}

Konsep kunci komunikasi organisasi keempat adalah keadaan yang saling tergantung satu bagian dengan bagian lainnya. Hal ini telah menjadi sifat dari suatu organisasi yang merupakan suatu sistem terbuka. Bila suatu bagian dari organisasi mengalami gangguan maka akan berpengaruh kepada bagian lainnya dan mungkin juga kepada seluruh sistem organisasi.

Hal ini pada dilihat pada kelompok Tani Tunas Makmur, yang memiliki struktur serta anggota yang cukup banyak. permasalahan satu pokja dapat mempengaruhi perkembangan pojka lainnya. Seperti hubungan saling ketergantungan antara Pokja Pertanian Nanas dan Pokja Pengolahan Produk Nanas. Pokja Pertanian Nanas yang mengurus pertanian dari penanaman hingga panen, yang akhirnya akan memberikan pasokan buah nanas untuk produksi produk olahan nanas. Namun, ketika nanas belum memasuki waktu panen ataupun ketika tidak stok buah yang ada di kelompok, maka kegiatan pengolahan produk nanas tidak dapat berjalan lantaran tidak terdapat bahan baku produksi. Sedangkan Pojka Pertanian Nanas akan kesulitan untuk menjual buah nanas hasil panen jika Pokja Pengolahan Produk Nanas tidak memerlukan bahan produksi. Hal ini membuat hubungan antar Pokja semakin ketergantungan atas dasar kebutuhan keberlangsungan Pokja.

\section{Hubungan}

Konsep kunci yang kelima dari komunikasi organisasi adalah hubungan. Karena organisasi merupakan suatu sistem terbuka, sistem kehidupan sosial maka untuk berfungsinya bagianbagian itu terletak pada tangan manusia. Dengan kata-kata lain jaringan melalui mana jalannya pesan dalam suatu organisasi dihubungkan oleh manusia. "Keefektifan hubungan antarpribadi ditentukan oleh kemampuan dalam mengkomunikasikan secara jelas apa yang ingin disampaikan, menciptakan kesan yang diinginkan, atau bagaimana mempengaruhi orang lain" (Supratiknya, 1995).

Dalam hal ini, kelompok Tani Tunas Makmur dapat dibilang memiliki hubungan yang baik didasari oleh kedekatan budaya (cultural proximity) yang mayoritas penduduk telah saling mengenal sejak lama dan berbudaya melayu islam. Komunikasi yang terjalin sangat efektif dikarenakan kesamaan bahasa, budaya komunikasi, serta lingkungan anggota kelompok. Selain itu, anggota kelompok yang merupakan warga kelurahan Sungai Pakning memiliki sejarah yang sama dalam menghadapi kasus kebakaran lahan dan kabut asap sehingga proximity yang terdapat ditiap anggota menjadi lebih kuat untuk mengembangan potensi kelompok.

\section{Lingkungan}

Lingkungan adalah semua totalitas secara fisik dan faktor sosial yang diperhitungkan dalam pembuatan keputusan mengenai individu dalam suatu sistem. Lingkungan ini dapat dibedakan atas lingkungan internal dan lingkungan eksternal. Yang termasuk lingkungan internal adalah personalia (karyawan), staf, golongan fungsional dari organisasi, dan komponen organisasi lainnya seperti tujuan, produk dan sebagainya. Sedangkan lingkungan eksternal dari organisasi adalah langganan, leveransir, saingan dan teknologi (Muhammad, 2009).

\section{Ketidakpastian}

Ketidakpastian adalah perbedaan informasi yang tersedia dengan informasi yang diharapkan. Untuk mengurangi faktor ketidakpastian ini organisasi menciptakan dan menukar pesan di antara anggota, melakukan suatu penelitian, pengembangan organisasi, dan menghadapi tugas-tugas yang kompleks dengan integrasi yang tinggi. Ketidakpastian dapat disebabkan oleh terlalu sedikit informasi yang diperlukan dan juga karena terlalu banyak yang diterima. Maka dari itu, peranan struktur kelompk dalam proses 
penyampaian pesan sangatlah penting untuk mengurangi ketidakpastian serta miskomunikasi antar anggota kelompok. Information overload dapat mengakibatkan kebingungan, maka dari itu kelompok Tani Tunas Makmur yang memilliki sistem komunikasi top-down serta terpusat sangat efektif dalam mengatasi hal tersebut.

Kelompok Tani Tunas Makmur telah melalui 7 tahapan tersebut sehingga komunikasi organisasi yang terdapat di kelompok ini efektif dalam menanggulangi konflik sosial yang terdapat di Kampung Jawa, kelurahan Sungai Pakning. Resolusi konflik yang telah dicapai berupa:

1. Kasus kebakaran lahan, yang mengakibatkan penyakit asma dan ISPAdapat diatasi melalui Program Pertanian Nanas dan Arboretum Gambut. Dalam program ini, Pertamina RU II Sungai Pakning juga memberikan bantuan berupa pembuatan sekat kanal, kanal, dan embung untuk meningkatkan air di lahan gambut. Selain itu, Arboretum Gambut yang memiliki flora kantong semar kerap menjadi lokasi edukasi bagi anak-anak hingga penelitian.

2. Peningkatan Ekonomi, yang sebelumnya masyarakat Kampung Mayoritas bekerja sebagai petani karet dapat meningkatkan perekonomian melalui pertanian nanas. Serta kesempatan lapangan kerja bagi ibu-ibu di Pokja pengolahan nanas untuk produk olahan keripik, dodol, manisan, sirup, serta selai nanas.

Faktor lain yang menyebabkan kelompok Tani Tunas Makmur berlangsung baik dalam menanggulangi konflik sosial adalah kuatnya nilai pertukaran sosial yang didapatkan masyarakat melalui program CSR Kampung Gambut Berdikari. Teori pertukaran sosial adalah sebuah perspektif sosiologi yang menjelaskan tentang perubahan sosial dan stabilitas sebagai sebuah proses pertukaran negosiasi antara berbagai macam pihak. Teori ini menyatakan bahwa hubungan antar manusia dibentuk oleh analisis untungrugi subjektif dan perbandingan dari berbagai alternatif yang tersedia (Rakhmat, 2001). Asumsi dasar teori pertukaran sosial adalah bahwa setiap individu secara sukarela memasuki dan tinggal dalam hubungan sosial hanya selama hu- bungan itu cukup memuaskan ditinjau dari segi ganjaran dan biaya.

Dalam segi pertukaran sosial, anggota yang bergabung di kelompok Tani Tunas Makmur mendapatkan ganjaran yang memuaskan sehingga anggota kelompok secara sukarela tetap bertahan. Ganjaran yang didapat berupa peningkatan pendapatan, relasi, serta keadaan lingkungan yang lebih sehat. Komunikasi organisasi yang efektif serta nilai tukar sosial yang kuat dapat menjadi resolusi bagi konflik sosial yang terjadi di suatu lingkungan sosial.

\section{SIMPULAN}

Kompleksitas komunikasi seringkali terjadi. Hal ini dapat mengakibatkan miskomunikasi hingga menimbulkan konflik, maka dari itu efektivitas komunikasi sangat dibutuhkan. Sistem komunikasi yang baik serta efektif dapat menunjang kelompk untuk dapat lebih bekerjasama dalam melaksanakan aktivitas, hingga mencapai resolusi permasalahan sosial. Kampung Jawa merupakan daerah yang cukup terisolir dari berbagai akses, maka dari itu penguatan antar individu kelompok melalui komunikasi organisasi sangat penting agar kelompok dapat mencapai solusi atas permasalahan yang ada.

\section{DAFTAR RUJUKAN}

Arni, Muhammad. 2009. Komunikasi Organisasi. Jakarta: Bumi Aksara

A. Supratiknya. 1995. Komunikasi Antar Pribadi. Yogyakarta: Kanisius

Goldhaber, Gerald. 1993. Organizational Communication. Boston: McGraw-Hill Publishing

Hidayat, dkk. 2018. Utilization of Georaphic Information (GIS) for the Prevention of Land and Forest Fires As Mitigation Efforts For Peatland Disaster. Atlantis Press

Jalaluddin Rakhmat. 2001. Psikologi Komunikasi. Bandung: PT Remaja Rosdakarya

Rudito, Bambang, dan Melia Famiola. 2013. Corporate Social Responsibility (CSR). Bandung: Rekayasa Sains

Rahmad Hidayat dan Miftah Faridl Widhagdha. 
2018. Pemetaan Sosial, Program Community Development PT Pertamina RU II Sungai Pakning 2017. Solo: Arjuna Wijaya Karya.

Widhagdha, dkk. 2018. CSR: Pemberdayaan Masyarakat di Lahan Gambut. Solo: Arjuna Wijaya Karya

Widhagdha, dkk. 2019. Modal Sosial dalam
Penanggulangan Bencana Asap di Riau: Penguatan Kelembagaan Sosial melalui Pemberadayaan Masyarakat Peduli Api. Widhagdha, dkk. 2019.ParticipatoryDevelopment Communication in Mitigating Forest and Land Fires in Riau Province. Proceeding of CCCMS 2019

Wiryanto. 2006. Pengantar Ilmu Komunikasi. Jakarta: Grasindo 